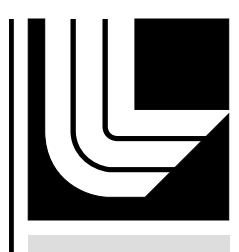

LAWRENCE LIVERMORE N A T IO N A L LABORATORY

CORROSION RESISTANCE OF STRUCTURAL AMORPHOUS METAL

T. Lian, S. D. Day, J. C. Farmer

April 10, 2006 
This document was prepared as an account of work sponsored by an agency of the United States Government. Neither the United States Government nor the University of California nor any of their employees, makes any warranty, express or implied, or assumes any legal liability or responsibility for the accuracy, completeness, or usefulness of any information, apparatus, product, or process disclosed, or represents that its use would not infringe privately owned rights. Reference herein to any specific commercial product, process, or service by trade name, trademark, manufacturer, or otherwise, does not necessarily constitute or imply its endorsement, recommendation, or favoring by the United States Government or the University of California. The views and opinions of authors expressed herein do not necessarily state or reflect those of the United States Government or the University of California, and shall not be used for advertising or product endorsement purposes.

This work was performed under the auspices of the U.S. Department of Energy by University of California, Lawrence Livermore National Laboratory under Contract W-7405-Eng-48. 


\title{
CORROSION RESISTANCE OF STRUCTURAL AMORPHOUS METAL
}

\author{
T. Lian, S. D. Day, \& J. C. Farmer \\ Lawrence Livermore National Laboratory
}

\section{INTRODUCTION}

Corrosion costs the Department of Defense billions of dollars every year, with an immense quantity of material in various structures undergoing corrosion. For example, in addition to fluid and seawater piping, ballast tanks, and propulsions systems, approximately 345 million square feet of structure aboard naval ships and crafts require costly corrosion control measures. The use of advanced corrosion-resistant materials to prevent the continuous degradation of this massive surface area would be extremely beneficial. The potential advantages of amorphous metals have been recognized for some time [Latanison 1985]. Iron-based corrosion-resistant, amorphous-metal coatings under development may prove important for maritime applications [Farmer et al. 2005].

Such materials could also be used to coat the entire outer surface of containers for the transportation and longterm storage of spent nuclear fuel, or to protect welds and heat affected zones, thereby preventing exposure to environments that might cause stress corrosion cracking [Farmer et al. 1991, 2000a, 2000b]. In the future, it may be possible to substitute such high-performance iron-based materials for more-expensive nickel-based alloys, thereby enabling cost savings in a wide variety of industrial applications. It should be noted that thermal-spray ceramic coatings have also been investigated for such applications [Haslam et al. 2005].

This report focuses on the corrosion resistance of a yttrium-containing amorphous metal, SAM1651. SAM1651 has a glass transition temperature of $\sim 584^{\circ} \mathrm{C}$, a recrystallization temperature of $\sim 653^{\circ} \mathrm{C}$, and a melting point of $\sim 1121^{\circ} \mathrm{C}$. The measured critical cooling rate for SAM1651 is $\leq 80 \mathrm{~K}$ per second, respectively. The yttrium addition to SAM1651 enhances glass formation, as reported by Guo and Poon [2003]. The corrosion behavior of SAM1651 was compared with nickel-based Alloy 22 in electrochemical polarization measurements performed in several highly concentrated chloride solutions.

\section{EXPERIMENTS}

Corrosion tests were performed on as-received SAM1651 vacuum arc-melted drop cast ingots. The ingots were cast into cylindrical molds to form long rods with a nominal diameter of 4-5 millimeters and a length of $\sim 75$ millimeters. The nominal composition of SAM1651 material is listed in Table 1. Two SAM1651 ingots, identified as \#0005 and \#19643 were mounted in an epoxy rod that exposes the ingot in cross section (4-5 mm diameter) for electrochemical testing. The epoxy-mounted specimens were ground with abrasive papers and given a 600-grit silicon carbide finish.

A temperature-controlled, borosilicate glass (Pyrex) cell was used for the electrochemical tests. This five-port cell had a working electrode (the test specimen), a reference electrode, and a counter electrode. A standard silver silver-chloride electrode, filled with near-saturation potassium chloride solution, was used as the reference, and communicated with the test solution via a Luggin probe placed in close proximity to the working electrode to minimize Ohmic losses. Numerical corrections for the reference electrode junction potential have been estimated, and have been found to be insignificant (Farmer et al. 2000a). The Luggin probe is equipped with a water-cooled jacket to keep the reference electrode at ambient temperature, thereby maintaining an accurate potential measurement. A water-cooled condenser was inserted into the vessel to prevent the loss of volatile species from the electrolyte. The solution was deaerated using a bubbled nitrogen gas purge through a fifth port (see Figure 1).

Each electrochemical test includes a potentiodynamic polarization measurement after a 24-hour immersion in test solutions. A scan rate of $0.167 \mathrm{mV} / \mathrm{s}$ (or $600 \mathrm{mV} / \mathrm{hr}$ ) was used in the potentiodynamic scans. The test solutions 
included $3.5 \mathrm{~m} \mathrm{NaCl}, 6 \mathrm{~m} \mathrm{NaCl}, 5 \mathrm{M} \mathrm{CaCl}_{2}$, and seawater from Half Moon Bay, California. All tests were conducted at $90^{\circ} \mathrm{C}$.

The Alloy 22 test data was generated on 5/8 inch diameter disc specimens. The composition of Alloy 22 is also listed in Table 1.

\section{RESULTS AND CONCLUSIONS}

Figure 2 shows the polarization behavior of SAM 1651 ingot $\# 19643$ in seawater at $90^{\circ} \mathrm{C}, 3.5$ molal $\mathrm{NaCl}$ at $90^{\circ} \mathrm{C}$, and $5 \mathrm{M} \mathrm{CaCl}_{2}$ at $105^{\circ} \mathrm{C}$. SAM 1651 has demonstrated excellent corrosion resistance based on the results of these polarization measurements.

In Figure 3, the polarization behavior of SAM1651 is compared to Alloy 22 in $5 \mathrm{M} \mathrm{CaCl}_{2}$ at $105^{\circ} \mathrm{C}$. SAM1651 shows higher breakdown potential than Alloy 22, an indication of better resistance to localized corrosion. Figure 4 also shows that SAM1651 has a comparable corrosion resistance to Alloy 22 in $6 \mathrm{~m} \mathrm{NaCl}$ solutions at temperatures near the electrolyte boiling point.

Based on preliminary test results, SAM1651 demonstrates a promising corrosion resistance that is comparable to that of Alloy 22, the preferred material for the outer barrier of nuclear waste storage containers. Additional tests have been planned to fully characterize the corrosion performance of SAM1651 in a range of environments. Future tests will assess the corrosion behavior of SAM1651 thermal spray coatings on various metal substrates.

\section{ACKNOWLEDGMENTS}

Work was sponsored by the Defense Advanced Research Projects Agency (DARPA) Defense Science Office (DSO), and the United States Department of Energy (DOE) Office of Science and Technology International (OSTI). This work was done under the auspices of the U.S. DOE by Lawrence Livermore National Laboratory (LLNL) under Contract No. W-7405-Eng-48.

The HPCRM Team expresses their gratitude to sponsors for financial support, and supportive colleagues for making this work possible. A special thanks to Jeffrey Walker (DOE OSTI) and Leo Christodoulou (DARPA DSO) for sharing their insights and knowledge in fields of engineering and materials science, and for their innovative solutions to many of the technical problems that have been addressed. Professor Joseph Payer of Case Western Reserve University is also gratefully acknowledged. His guidance has helped the HPCRM Team reach its current level of scientific and technical success.

Samples of drop-cast ingots of SAM1651 were fabricated by Dr. Craig Blue and his colleagues at Oak Ridge National Laboratory. These materials were prepared under contract for Lawrence Livermore National Laboratory.

\section{REFERENCE}

J. C. Farmer et al., Nuclear Engineering Design, Vol. 129, pp. 57-88 (1991).

J. C. Farmer et al., Proc. 2000 ASME Pressure Vessel and Piping (PVP) Conference, Seattle, Washington, July 2327, 2000, Transportation, Storage, and Disposal of Radioactive Materials, American Society of Mechanical Engineers, New York, NY, PVP Vol. 408, pp. 53-70 (2000a).

J. C. Farmer et al., Proc. 2000 ASME Pressure Vessel and Piping (PVP) Conference, Seattle, Washington, July 2327, 2000, Transportation, Storage, and Disposal of Radioactive Materials, American Society of Mechanical Engineers, New York NY, PVP Vol. 408, pp. 71-81 (2000b). 
J. C. Farmer et al., Proc. 2005 ASME Pressure Vessel and Piping (PVP) Conference, Denver, Colorado, July 17-21, 2005, American Society of Mechanical Engineers, PVP2005-71664, New York, NY, 7 p. (2005a).

J. C. Farmer et al., DARPA-DOE High-Performance Corrosion-Resistant Materials Principal Investigator's Meeting, UCRL-PRES-214672, Turtle Bay Resort, Oahu, Hawaii, January 10-13, 2005, Lawrence Livermore National Laboratory, Livermore, California, 407 pages (2005b).

J. J. Haslam, J. C. Farmer, R. W. Hopper, K. R. Wilfinger, Ceramic Coatings for Corrosion Resistant Nuclear Waste Container Evaluated in Simulated Ground Water at 90C, UCRL-JRNL-206107; Metallurgical and Materials Transactions A, Volume 36A, May 2005, p. 1085-1095 (2004).

F. Guo, S. J. Poon, Applied Physics Letters, 83 (13) 2575-2577 (2003).

R. M. Latanison, Workshop on Amorphous Metals and Semiconductors, EPRI, May 12-18 (1985).

Table 1. Composition of SAM1651 and Alloy 22

\begin{tabular}{|l|c|c|c|c|c|c|c|c|c|}
\hline & Fe (\%) & Cr (\%) & Mo (\%) & C (\%) & Y (\%) & B (\%) & Ni (\%) & Co (\%) & W (\%) \\
\hline SAM1651 & 48.0 & 15.0 & 14.0 & 15.0 & 2.0 & 6.0 & & & \\
\hline Alloy 22 & 3.65 & 21.23 & 13.37 & 0.003 & & & 55.29 & 1.7 & 2.93 \\
\hline
\end{tabular}




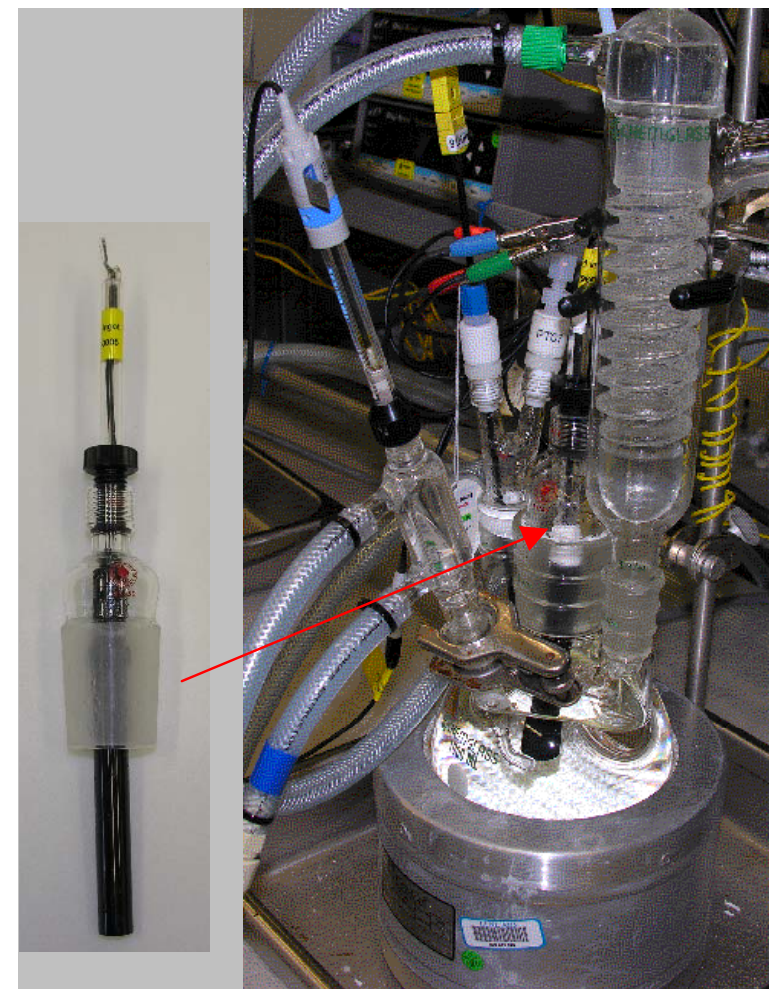

Figure 1. Electrochemical test apparatus.

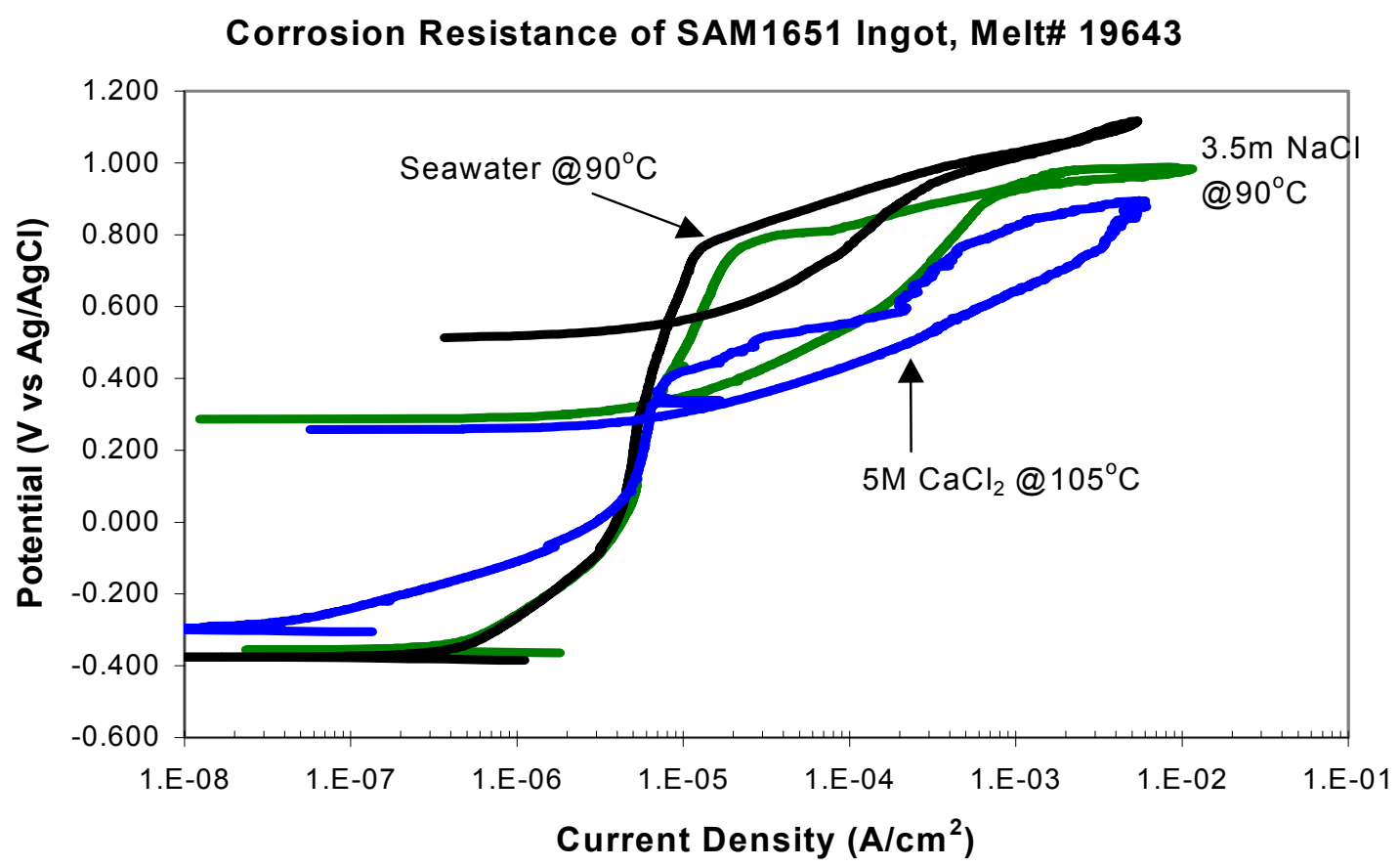

Figure 2. Electrochemical polarization behavior of SAM1651 material in various chloride solutions. 


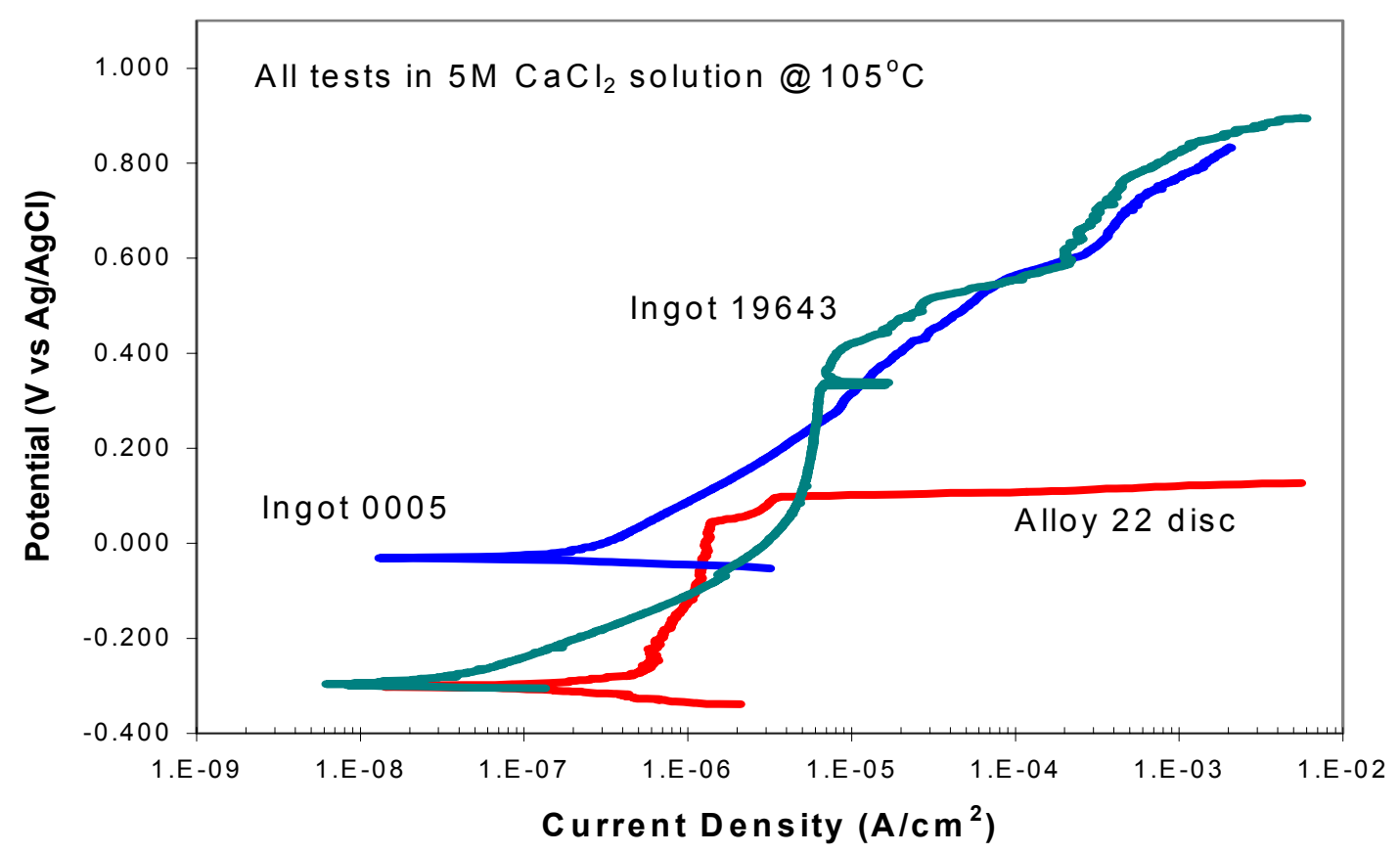

Figure 3. Comparison of Polarization Behavior Between SAM1651 Ingots and Alloy 22 Disc in $5 \mathrm{M} \mathrm{CaCl}_{2}$ Solution at $105^{\circ} \mathrm{C}$

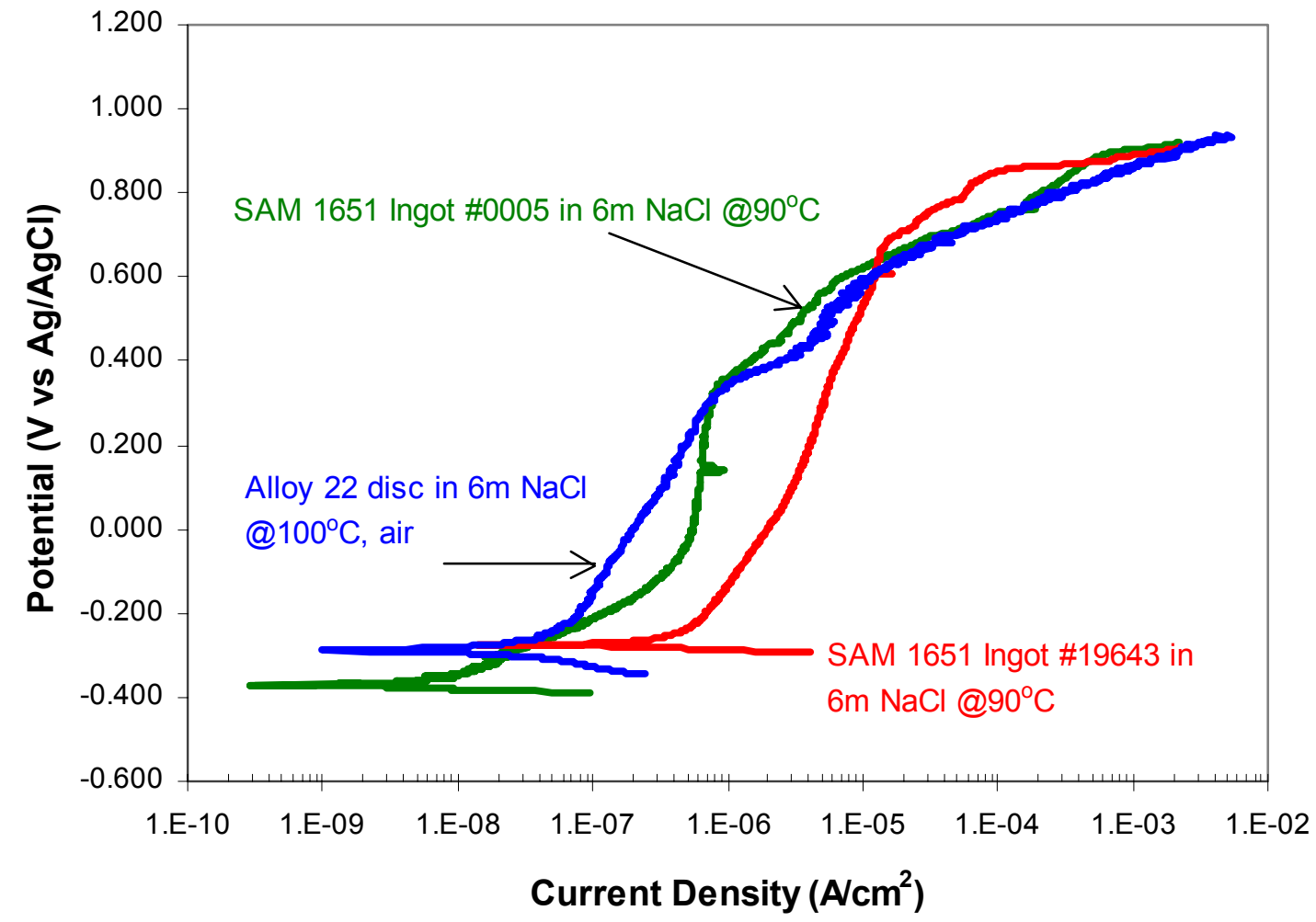

Figure 4. Comparison of polarization behavior between SAM1651 ingots and Alloy 22 disc, in $6 \mathrm{~m} \mathrm{NaCl} \mathrm{solutions}$ 